\title{
Morphometric analysis of Gorontalo (Indonesia) native chickens from six different regions
}

\author{
ALFI SOPHIAN $^{1,2}$, ABINAWANTO $^{1, \boldsymbol{}}$, UPI CHAIRUN NISA ${ }^{1}$, FADHILLAH $^{1}$ \\ ${ }^{1}$ Department of Biology, Faculty of Mathematics and Natural Sciences, Universitas Indonesia. J1. Prof. Dr. Sudjono D Pusponegoro (Lingkar UI), E \\ Building, UI Campus, Depok 16242, West Java, Indonesia. Tel.: +62-21-7270163, Fax.: +62-21-78829010, •email: abinawanto.ms@sci.ui.ac.id \\ ${ }^{2}$ National Agency of Drug and Food Control in Gorontalo (Balai POM di Gorontalo). Jl. Tengah Toto Selatan, Bone Bolango 96123, Gorontalo, \\ Indonesia
}

Manuscript received: 9 December 2020. Revision accepted: 13 March 2021.

\begin{abstract}
Sophian A, Abinawanto, Nisa UC, Fadhillah. 2021. Morphometric analysis of Gorontalo (Indonesia) native chickens from six different regions. Biodiversitas 22: 1757-1763. Research on the diversity of Gorontalo native chickens based on morphometric analysis of body weight, leg length, head length, head length to beak and head width was conducted. This study was conducted to identify the diversity of native chickens in six regions spread across Gorontalo Province, Indonesia. The method used in conducting statistical analysis is the principal component analysis (PCA) method. This method was performed to identify which morphometric factors play a role in relationship analysis of Gorontalo native chickens. Based on statistical analysis, it was found that of the 5 variables used in this study, 3 variables had Measure of Sampling Adequacy (MSA) values $>0.5$ ranged from 0.537 to 0.648 , namely body weight, leg length, and head length. Meanwhile, the other 2 variables, namely Head to Beak Length and Head Width, have MSA values $<0.5$ with values of 0.313 and 0.316 . This causes the other 2 variables to be used as a differentiating variable in analyzing the relationship between native chickens from six different regions scattered in the Gorontalo Province. The morphometric analysis of body weight means that the chickens sampled from Boalemo were morphometrically the largest in size, while the chickens sampled from Pohuwato were morphometrically the smallest. Chickens sampled from North Gorontalo, Bone Bolango, and Gorontalo City tended to be more uniform when compared to the chickens sampled from Pohuwato and Boalemo areas, while for Gorontalo District it was larger in size than Pohuwato, North Gorontalo, Bone Bolango, and Gorontalo City, but smaller than Boalemo.
\end{abstract}

Keywords: Diversity, Gorontalo, morphometric, native chicken

\section{INTRODUCTION}

Gorontalo native chickens are local chickens that the people of Gorontalo breed as livestock to fulfill their daily needs. Apart from meat, eggs are also an important economic value for people who raise free-range chickens. Compared to broilers, native chickens tend to have better body resistance to disease when compared to broilers (Desta and Wakeyon 2012). Thus, native chickens are preferred to be used as livestock compared to broilers. Free-range chicken is a unique genetic resource (Wragg et al. 2012; Wijayesena et al. 2014), a source of food security for rural households (Cabarles et al. 2012; Magothe et al. 2012; Desta et al. 2013). However, a comprehensive study on biodiversity of this unique genetic resource has not been done. The future challenge in researching the biodiversity of native chickens is how to analyze the diversity of species originating from different areas, finding what factors influence it, and determining what variables can be used as benchmarks in the analysis of its diversity. One type of approach that is commonly used to analyze species diversity is to use morphometric analysis.

Morphometrics deals with shape analysis and shape variation between specimens of a single population of distinct populations (Bookstein 1991; Slice 2007). Morphometrics is frequently used to answer various concerns about morphological evolution and species diversity by studying specific differentiation processes or quantifying morphological disparity through time and/or space. Moreover, it is increasingly used for evolutionary study (Laffont et al. 2011). Several reports show morphometric analysis was used to analyze the diversity of species in chickens. Liyanage et al. (2015) showed that body morphometrics can be used to analyze species diversity of local chickens and native chickens in Sri Lanka. In addition, morphometric analysis has been done also in Bangkok and dwarf chickens (Sitanggang et al. 2016), Indonesian local chickens (Mariandayani et al. 2013; Sitanggang et al. 2016), chicken Sentul, Kedu chicken and boiler chicken (Mariandayani et al. 2013). Several morphometric parts of the body that have been analyzed include shank length, trunk length, chest girth, comb length, body length, wing length, sternum length and shank circumference (Ferdaus et al. 2019). In Indonesia, similar research has been conducted by Putranto et al. (2018), wherein his research using Burgo chicken which was analyzed its diversity with native chickens.

So based on this background, this study was conducted to analyze the diversity of native chicken species sampled from six regions in Gorontalo Province through the body morphometric approach which never been done. The purpose of this research was to become a source of information in the future in conducting research related to the diversity of chicken species in a population or area. 
Besides, this research is expected to provide information about the local genetic resources of Gorontalo native chicken species.

\section{MATERIALS AND METHODS}

\section{Study area}

This research was conducted in 6 districts/cities Gorontalo Province, Indonesia, namely: Gorontalo City, Bone Bolango District, North Gorontalo District, Gorontalo District, Boalemo District, and Pohuwato District (Figure $1)$.

\section{Sample}

The sample used was 36 male native chickens, each sampled 5 chickens from 6 regions. The sample was then measured for body morphometrics, including body weight, leg length, head length, head to beak length, and head width. This parameter was selected from the part that was considered to be representative morphometrics in chickens for analysis.

\section{Statistic analysis}

The statistical analysis used to perform the morphometric analysis is PCA analysis (principal component analysis). This analysis was carried out to see which morphometric variables affected the diversity of Gorontalo native chickens which were sampled from 6 different regions. After knowing the influencing variables, a comparison analysis graph of the body morphometric mean of each sample area was made to compare the variability.

\section{RESULTS AND DISCUSSION}

\section{Morphometric data}

Samples used in this study were collected from six different regions. The chickens are shown in Figure 2.
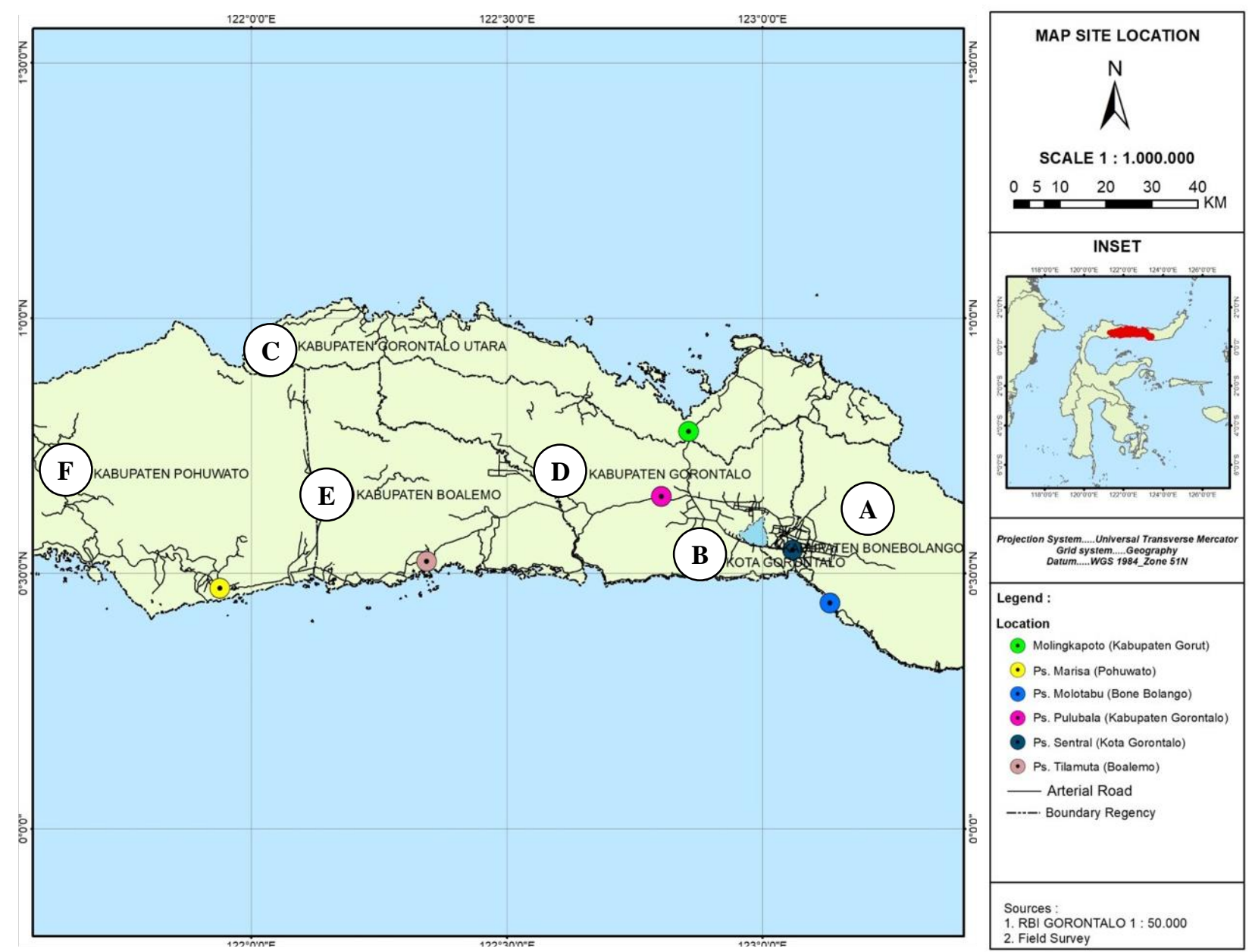

Figure 1. Map of research locations in Gorontalo Province, Indonesia. A. Gorontalo City, B. Bone Bolango District, C. North Gorontalo District, D. Gorontalo District, E. Boalemo District, F. Pohuwato District 
The morphometric analysis results showed that the average body weight of the Gorontalo City chicken was $1.53 \mathrm{~kg}$, Bone Bolango $1.53 \mathrm{~kg}$, North Gorontalo $1.51 \mathrm{~kg}$, Gorontalo District $1.67 \mathrm{~kg}$, Boalemo $1.79 \mathrm{~kg}$, Pohuwato $1.33 \mathrm{~kg}$. The average length of the leg length of the urban native chicken is $8.46 \mathrm{~cm}$, Bone Bolango is $8.50 \mathrm{~cm}$, North Gorontalo is $8,452 \mathrm{~cm}$, Gorontalo District is $8.76 \mathrm{~cm}$, Boalemo is $9.28 \mathrm{~cm}$, and Pohuwato is $8.12 \mathrm{~cm}$. The average length of the head of urban native chickens is 5.02 $\mathrm{cm}$, Bone Bolango $5.00 \mathrm{~cm}$, North Gorontalo $5.00 \mathrm{~cm}$, Gorontalo District $5.00 \mathrm{~cm}$, Boalemo $5.13 \mathrm{~cm}$, Pohuwato $5.02 \mathrm{~cm}$. The average length of the head to the beak of urban native chickens is $5.65 \mathrm{~cm}$, Bone Bolango $6.60 \mathrm{~cm}$, North Gorontalo $5.96 \mathrm{~cm}$, Gorontalo District $6.38 \mathrm{~cm}$, Boalemo $6.70 \mathrm{~cm}$, Pohuwato $6.30 \mathrm{~cm}$ and the average head width of urban native chickens is $3.06 \mathrm{~cm}$, Bone Bolango $3.00 \mathrm{~cm}$, North Gorontalo $3.00 \mathrm{~cm}$, Gorontalo District 3.00 $\mathrm{cm}$, Boalemo $3.00 \mathrm{~cm}$, Pohuwato $2.96 \mathrm{~cm}$. The complete morphometric average data are presented in Table 1.

Based on the morphometric data (Table 1), statistical analysis was then carried out. The first step taken is to test the adequacy of the sample or the feasibility of a variable through the Kaiser-Meyer-Olkin (KMO) and Bartlett's Test. The Kaiser-Meyer-Olkin Measure of Sampling Adequacy (KMO MSA) Index criteria and the significance value of Bartlett's Test of Sphericity are if the KMO value is between 0.5 to 1 and the significance of Bartlett's Test of Sphericity is less than the significance level $(\alpha=0.05)$ used means that factor analysis is appropriate to use. Based on the data from the processing results, it was found that the KMO MSA value was $0.522>0.5$ and Bartlett's Test of
Sphericity significance value was $0.000<0.05$, so it can be concluded that the factor analysis in this study can be continued because it meets the requirements.

The next step was continued with the Anti-image Matrice analysis (Table 2). This analysis is used to determine whether the research items are adequate and to determine what items are suitable for further analysis. To find out, it can be seen on the value of the matrix which has an "a" sign, which means a sign for the Measure of Sampling Adequacy (MSA). If the MSA value is greater than 0.5 then the item is sufficient for further analysis. If there is a variable with an MSA value $<0.5$, then the reanalysis process is carried out only on the variable with an MSA value> 0.5 .

From Table 2, it is known that of the 5 variables used in the study, 3 variables have MSA values > 0.5 with values ranging from 0.537 to 0.648 , namely Body Weight, Leg Length, and Head Length. While the other 2 variables, namely Head to Beak Length and Head Width, have MSA values $<0.5$ with values of 0.313 and 0.316 . So it can be concluded that the second requirement for factor analysis was not met. Therefore, retesting was done by excluding variables with MSA values $<0.5$.

The results of retesting the data using KMO and MSA analysis obtained a value of $0.567>0.5$ and a significance value of Bartlett's Test of Sphericity is $0.000<0.05$, so it can be concluded that the repeat analysis of the factors in this study is bodyweight, leg length, and head length can be continued for anti-image analysis because it meets the requirements.
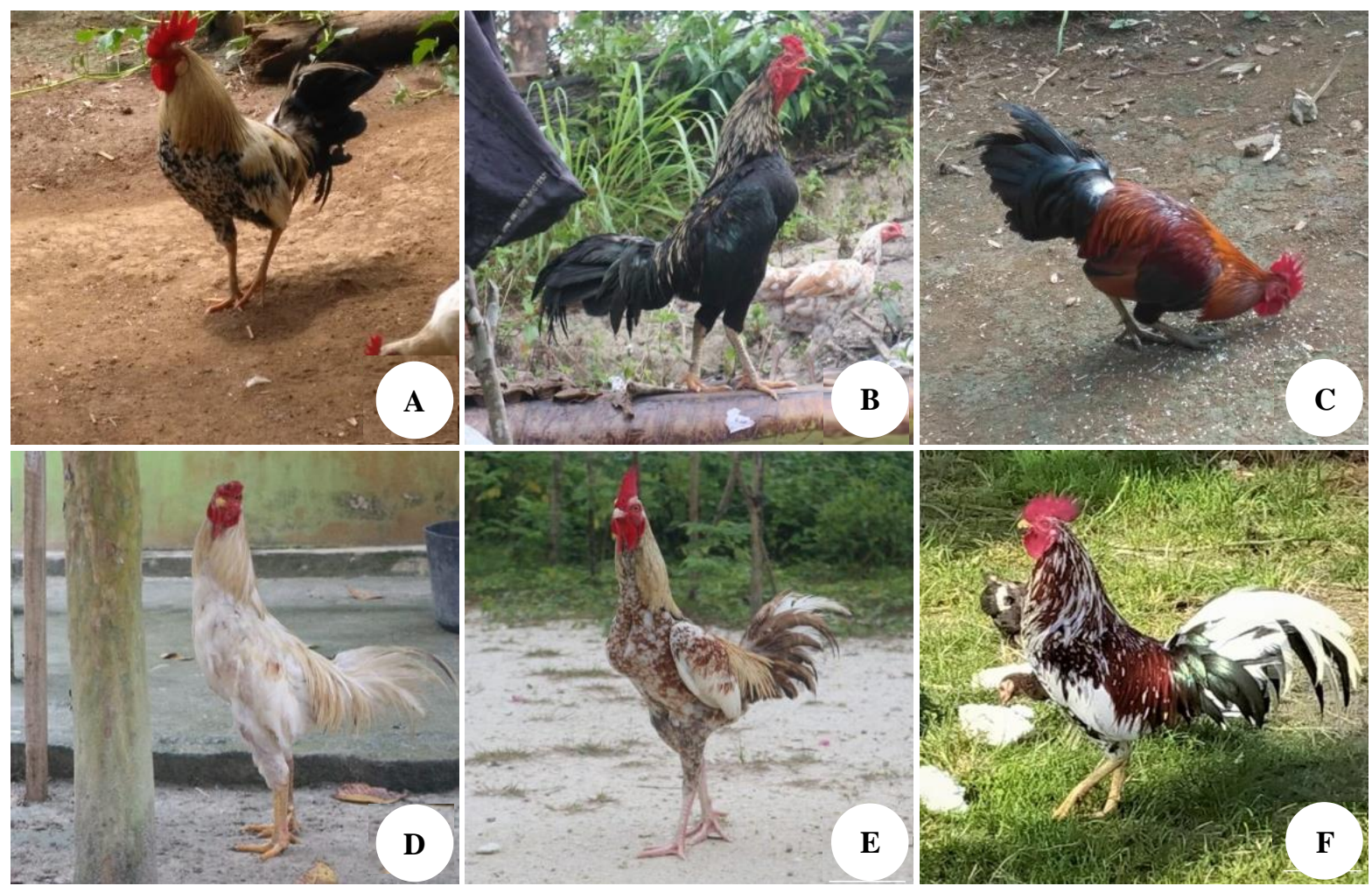

Figure 2. Sampled chickens from six different regions in Gorontalo Province, Indonesia. A. Gorontalo City, B. Bone Bolango District, C. North Gorontalo District, D. Gorontalo District, E. Boalemo District, F. Pohuwato District 
Table 1. Morphometric average data of Gorontalo (Indonesia) native chickens ( $\mathrm{n}=5$ of each location)

\begin{tabular}{lccccc}
\hline Sample location & Bodyweight $(\mathbf{k g})$ & Leg length $(\mathbf{c m})$ & Head length $(\mathbf{c m})$ & $\begin{array}{l}\text { Head to beak } \\
\text { length }(\mathbf{c m})\end{array}$ & Head width $(\mathbf{c m})$ \\
\hline Gorontalo City & 1.53 & 8.46 & 5.02 & 5.65 & 3.06 \\
Bone Bolango & 1.53 & 8.50 & 5.00 & 6.60 & 3.00 \\
North Gorontalo & 1.51 & 8.52 & 5.00 & 5.96 & 3.00 \\
Gorontalo District & 1.67 & 8.76 & 5.00 & 6.38 & 3.00 \\
Boalemo & 1.79 & 9.28 & 5.13 & 6.70 & 3.00 \\
Pohuwato & 1.33 & 8.12 & 5.02 & 6.30 & 2.96 \\
\hline
\end{tabular}

Table 2. Anti-image matrices analysis

\begin{tabular}{|c|c|c|c|c|c|c|}
\hline Parameters & & $\begin{array}{c}\text { Bodyweight } \\
(\mathrm{kg})\end{array}$ & $\begin{array}{l}\text { Leg length } \\
\text { (cm) }\end{array}$ & $\begin{array}{l}\text { Head length } \\
(\mathrm{cm})\end{array}$ & $\begin{array}{c}\text { Head to beak } \\
\text { length }(\mathrm{cm})\end{array}$ & $\begin{array}{l}\text { Head width } \\
\text { (cm) }\end{array}$ \\
\hline Anti-image & Body weight (kg) & .228 & -.156 & .039 & .112 & -.137 \\
\hline \multirow[t]{4}{*}{ Covariance } & Leg length $(\mathrm{cm})$ & -.156 & .168 & -.142 & -.051 & .047 \\
\hline & Head length $(\mathrm{cm})$ & .039 & -.142 & .410 & -.115 & .154 \\
\hline & Head to beak length $(\mathrm{cm})$ & .112 & -.051 & -.115 & .726 & -.339 \\
\hline & Head width $(\mathrm{cm})$ & -.137 & .047 & .154 & -.339 & .633 \\
\hline Anti-image & Body weight (kg) & $.537^{\mathrm{a}}$ & -.796 & .128 & .275 & -.360 \\
\hline \multirow[t]{4}{*}{ Correlation } & Leg length $(\mathrm{cm})$ & -.796 & $.559^{\mathrm{a}}$ & -.542 & -.145 & .144 \\
\hline & Head length $(\mathrm{cm})$ & .128 & -.542 & $.648^{\mathrm{a}}$ & -.211 & .302 \\
\hline & Head to beak length $(\mathrm{cm})$ & .275 & -.145 & -.211 & $.313^{\mathrm{a}}$ & -.499 \\
\hline & Head width $(\mathrm{cm})$ & -.360 & .144 & .302 & -.499 & $.316^{\mathrm{a}}$ \\
\hline
\end{tabular}

Note: a: Measures of Sampling Adequacy (MSA)

Table 3. Anti-image matrices analysis of retest results

\begin{tabular}{llccc}
\hline Parameters & & Body weight $(\mathbf{k g})$ & Leg length $(\mathbf{c m})$ & Head length $(\mathbf{c m})$ \\
\hline Anti-image covariance & Body weight $(\mathrm{kg})$ & .266 & -.173 & .096 \\
& Leg length $(\mathrm{cm})$ & -.173 & .173 & -.177 \\
& Head length $(\mathrm{cm})$ & .096 & -.177 & .453 \\
Anti-image correlation & Body weight $(\mathrm{kg})$ & $.570^{\mathrm{a}}$ & -.804 & .278 \\
& Leg length $(\mathrm{cm})$ & -.804 & $.539^{\mathrm{a}}$ & -.631 \\
& Head length $(\mathrm{cm})$ & .278 & -.631 & $.614^{\mathrm{a}}$ \\
\hline
\end{tabular}

Note: a: Measures of Sampling Adequacy (MSA)

From the Table 3 , it is known that of the 3 variables tested again, all of them had MSA values> 0.5 with values ranging from 0.539 to 0.614 , namely Body Weight, Leg Length, and Head Length. Then it can be concluded that the second requirement for factor analysis is met. The results of the extraction method using principal component analysis showed that body weight, leg length and head length have values ranging from 0.668 to 0.929 where all items have a value greater than 0.5 , it can be concluded that all research items can be used to explain the pattern of relationship relationships between native chickens located in 6 districts/ cities, i.e. Puhuwato District, Boalemo District, North Gorontalo District, Gorontalo District, Bone Bolango District, and Gorontalo City.

The analysis was then continued to see from the three factors, which factor had the greatest impact to analyze the relationship between the diversity of Gorontalo native chickens. The number of factors to be formed is determined by combining several criteria to obtain the number of factors that best match the research data. The Total Variance Explained analysis results show the value of each item analyzed in this study where there are 3 components, which means that 3 items are being analyzed. There are 2 types of analysis from the table above to explain a variance, namely Initial Eigenvalues and Extraction Sums of Squared Loadings.

The first criterion used is the Initial Eigenvalues that have been determined in SPSS, namely 1 . Factors that have an eigenvalue more than 1 will be maintained, and factors with an eigenvalue less than 1 will not be included in the model. From the table above, it is obtained that the eigenvalues are greater than 1, there is 1 component, namely in component 1 .

The second criterion is the determination based on the percentage of variance which can be explained by the number of factors to be formed. From the table above, it can be interpreted concerning the cumulative total variance of the sample. If the variables are summarized into several components, the total variance value can be explained as follows. If 3 items are extracted into 1 component, a total variance of $2.380 / 3 \times 100 \%=79.323 \%$., If 3 items are extracted into 2 components, a total variance of $0.514 / 3 \mathrm{x}$ $100 \%=17.122 \%$ is obtained and if 3 items are extracted it becomes 3 components, obtained a total variance of 0.107 / 
$3 \times 100 \%=3.555 \%$. By simplifying the initial research items into 1 component, the resulting cumulative total variance can explain the total items of $79.323 \%$, meaning that from 1 factor formed can represent the 3 research items used.

The third criterion is a determination based on the scree plot. The scree plot is a plot of the eigenvalues against the number of components formed which can be seen by looking at the component points that have eigenvalues> 1 . From the analysis, the results show that there is 1 component point that has an eigenvalue> 1 , it can be concluded that there is 1 component. which can be formed to represent the 3 research items used.

The Component matrix analysis results show the correlation value or the relationship between each variable and the formed factors. After it is known that 1 component is the most optimal number, the component matrix table shows the distribution of the 3 research items in 1 formed component. In contrast, the numbers in the table are factor loadings, which shows the magnitude of the correlation between the research items and the components formed. Based on the analysis, it is known that Body Weight $(\mathrm{Kg})$ has a correlation value with component 1 of 0.885 , Leg Length $(\mathrm{cm})$ has a correlation value with component 1 of 0.964 , and Head Length $(\mathrm{cm})$ has a correlation value with component 1 of 0.818 .

So based on the results of statistical analysis, of the five morphometric variables analyzed, 2 variables were considered unable to be used as variables to analyze the patience relationship of Gorontalo native chickens which were spread out in six sampling areas, the two variables were head to beak length and head width. However, 3 variables can be used as parameters to analyze the diversity of Gorontalo native chickens, namely body weight, leg length, and head length.

Research conducted by Iskandar et al. (2006) revealed that body weight can be used to analyze species diversity in native chickens. In his research, which was conducted on native chickens, the results were quite varied between native chickens sampled from several locations. A study conducted by Petrus et al (2011), found that the weight of chickens in each Sherpur district in Bangladesh can be used to perform diversity analysis. Tabassum et al. (2014) did the same thing but got different results. In general, uniform results have been found that body weight in chickens is a morphometric part that is often used to analyze the diversity of species variations in local chickens (Negassa et al. 2014; Al-Qamashoui et al. 2014). Meanwhile, there are other studies reveal that leg length can be used to analyze the diversity of local chicken species (Guni and Katule 2013; Badubi et al. 2006).

In Figure 3, it can be seen that in the parameter of leg length, the chickens sampled from Boalemo have a longer size when compared to other areas, as well as in the parameters of head length and body weight. Morphometrically, the sampled chickens from Boalemo had a heavier body weight compared to the chickens sampled from other regions, while for lighter body weights were occupied by the chickens sampled from Pohuwato. Likewise, with the length of the legs, the chickens sampled from Boalemo morphometrically had a longer leg length compared to chickens sampled from other areas, while for the shortest leg lengths the chickens sampled from Pohuwato had. Similar to the length of the head, the chickens sampled from Boalemo morphometrically had a longer head size when compared to the chickens sampled from other areas, while the smaller head sizes were owned by the chickens sampled from Pohuwato. Chickens sampled from North Gorontalo, Bone Bolango, and Gorontalo City districts tended to be more uniform when compared to the Pohuwato and Boalemo areas, while for Gorontalo District it was larger in size than Pohuwato, North Gorontalo, Bone Bolango, and Gorontalo City, but smaller than Boalemo. The differences in this variation can be caused by several factors, including genetic and environmental factors. Besides that, Boalemo as an area that has more agricultural resources when compared to other regions is also the main factor why the morphometric growth of native chickens from this area is quite high when compared to other regions.

The phenotype morphometric trait of the body can be influenced by the number of gene pairs (polygenes) and is also influenced by environmental factors. Developmental factors (Young et al. 2017), and domestication factors are two things that also play a role in the morphometric diversity of poultry (Felice and Goswami 2018; Bright et al 2016). When viewed from environmental geographic conditions, the samples sampled from urban areas (Gorontalo City) tend to have a relationship with Bone Bolango, Gorontalo District, and North Gorontalo. This is because the city area is a trading center where the source of chickens that are traded in this region can come from other areas. This is one reason why the results of the body morphometric analysis of chickens in these three locations tend to be more similar compared to other areas. Geographical factors influence the isolation pattern and diversity of chicken species (Ngeno et al. 2014; Moraa et al. 2015). Lyimo et al. (2014), in their research, analyzed the relationship between heterogeneity in natural and artificial stresses and research conducted by Desta et al. (2013) and Bettridge et al. (2018).

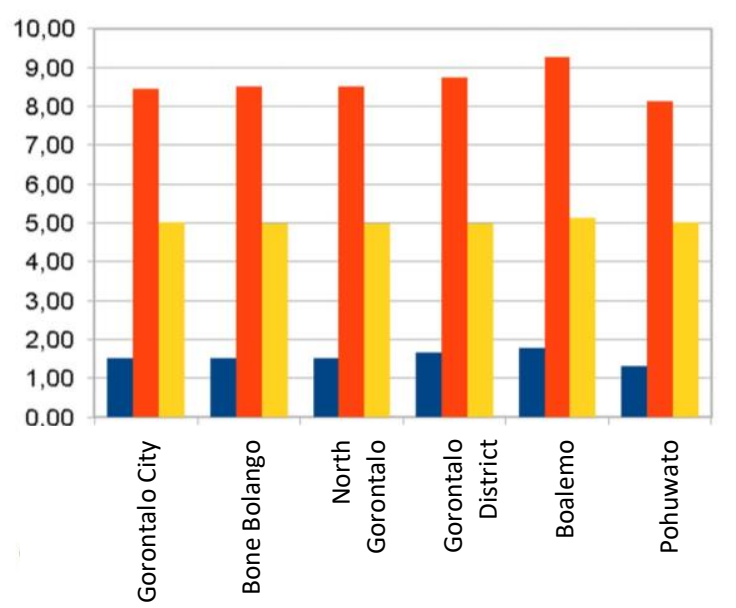

Figure 3. Morphometric measurement of Gorontalo native chickens, Indonesia. Note: Body weight $(\mathrm{kg})$, $\square$ Leg length $(\mathrm{cm}), \square$ Head length $(\mathrm{cm})$ 
Morphometric can also be used to analyze the quality of good superior seeds. The parts of the body that are measured can provide information about body weight. This is in line with research conducted by Assan (2013), who conducted a morphometric analysis which was curated with bodyweight to classify the quality of chickens. If we look at Figure 2, the results of statistical tests on 3 influencing variables to analyze the diversity of chicken species in six regions in Gorontalo, it is concluded that one of the three variables can be used to represent each other, meaning body weight, leg length and the length of the head can be selected as a variable that represents the other variables. This is because each body's morphometric size is influenced by body shape, where physically and the chickens sampled from the Boalemo area have a larger body shape and size compared to other areas. If further analyzed, these three variables can be used to analyze the quality of native chickens that are scattered in several areas where chickens that have a large shape tend to be more expensive if they are sold as a source of economic income when compared to chickens with smaller body weights. This is because in buying and selling livestock, body weight can be used to see the weight of livestock meat.

As a conclusion in this study, the variables of body weight, leg length, and head length are variables that can be used to perform morphometric analysis to see the level of species diversity in chickens from different sampling locations. Furthermore, this research provides new information about the local genetic resources of native chicken in Indonesia, especially, Gorontalo native chicken species.

\section{ACKNOWLEDGEMENTS}

The authors would like to thank the Indonesian Ministry of Research and Technology/National Research and Innovation Agency for the financial support through the PDUPT with contract no. NKB2793/UN2.RST/HKP.05.00/2020.

\section{REFERENCES}

Al-Qamashoui B, Mahgoub O, Kadim I, Schlecht E. 2014. Towards conservation of Omani local chicken: Phenotypic characteristics, management practices and performance traits. Asian-Australasian J Anim Sci 6: 174-182. DOI: 10.5713/ajas.2013.13541.

Assan N. 2013. Bio prediction of body weight and carcass parameters from morphometric measurements in livestock and poultry. Sci J Rev 2 (6): 140-150

Bettridge JM, Psifidi A, Terfa ZG, Desta TT, Lozano-Jaramillo M, Dessie T, Kaiser P, Wigley P, Hanotte O, Christley RM. 2018. The role of local adaptation in sustainable production of village chickens. Nat Sustain 1: 574-582. DOI: 10.1038/s41893-018-0150-9.

Bookstein FL. 1991. Morphometric Tools for Landmark Data: Geometry and Biology. Cambridge University Press, Cambridge. DOI: 10.1017/CBO9780511573064.

Bright JA, Marugán-Lobón J, Cobb SN, Rayfield EJ. 2016 The shapes of bird beaks are highly controlled by nondietary factors. Proc Natl Acad Sci USA 113: 5352-5357. DOI: 10.1073/pnas.1602683113.

Cabarles Jr JC, Lambio AL, Vega SA, Captain SS, Mendioro, MS. 2012. Distinct morphological features of traditional chickens (Gallus gallus domesticus L.) in Western Visayas, Philippines. Anim Genet Resour FAO 51: 73-87. DOI: 10.1017/S2078633612000410.

Desta TT, Dessie T, Bettridge J, Lynch SE, Melese K, Collins M, Christley RM, Wigley P, Kaiser P, Terfa Z, Mwacharo JM, Hanotte O. 2013. Signature of artificial selection and ecological landscape on morphological structures of Ethiopian village chickens. Anim Genet Resour 52:17-29. DOI: 10.1017/S2078633613000064.

Desta TT, Wakeyo O. 2012. Uses and flock management practices of scavenging chickens inWolaita Zone of Southern Ethiopia. Trop Anim Health Prod 44:537-544. DOI: 10.1007/s11250-011-9933-y.

Felice RN, Goswami A. 2018 Developmental origins of mosaic evolution in the avian cranium. Proc Natl Acad Sci USA 115: 555-560. DOI: 10.1073/pnas.1716437115.

Ferdaus AJM, Ali MS, Hassin BM, Bhuiyan AKFH, Bhuiyan MSA. 2019. Body conformation, morphometry indices and inherit pattern of indigenous Dwarf chickens of Bangladesh. J Poult Res 16 (2): 55-61. DOI: $10.34233 /$ jpr.605051.

Guni FS, Katule AM. 2013. Characterization of local chickens in selected districts of the Southern Highlands of Tanzania: I. Qualitative characters. Livest Res Rural Dev 25 (9): 153. www.lrrd.org/lrrd25/9/guni25153.

Laffont R, Firmat C, Alibert P, David B, Montuire S, Saucede T. 2011. Biodiversity and evolution in the light of morphometrics: From patterns to processes. C R Palevol 10 (2011): 133-142. DOI:10.1016/j.crpv.2010.10.004.

Lyimo CM, Weigend A, Msoffe PL, Eding H, Simianer H, Weigend S. 2014. Global diversity and genetic contributions of chicken populations from African, Asian and European regions. Anim Genet 45:836-848. DOI: 10.1111/age.12230.

Liyanage RP, Dematawewa CMB, Silva GLLP. 2015. Comparative study on morphological and morphometric features of village chicken in Sri Lanka. Trop Agric Res 26 (2): 261-273. DOI: 10.4038/tar.v26i2.8090.

Magothe TM, Okeno TO, Muhuyi WB, Kahi AK. 2012. Indigenous chicken production in Kenya: I. Current status. Worlds Poult Sci J 68:119-132. DOI: 10.1017/S0043933912000128.

Mariandayani HN, Solihin DD, Sulandari S, Sumantri C. 2013. Phenotypic variation and estimation of genetic distance between local chicken and broiler chicken using morphological analysis. J Veteriner 14 (4): 475-484. [Indonesian].

Moraa GK, Oyier PA, Maina SG, Makanda M, Ndiema EK, Alakonya AE, Ngeiywa KJ, Lichoti J, Ommeh SC. 2015. Assessment of phenotypic traits relevant for adaptation to hot environments in indigenous chickens from four agro-climatic zones of Kenya. Livest Res Rural Dev 27:200. www.lrrd.org/lrrd27/10/omme27200.

Negassa D, Melesse A, Banerjee S. 2014. Phenotypic characterization of indigenous chicken populations in Southeastern Oromia Regional State of Ethiopia. Anim Genet Resour 55: 101-113. DOI: $10.1017 /$ S2078633614000319.

Ngeno K, van der Waaij EH, Megens HJ, Kahi AK, van Arendonk JAM, Crooijmans RPMA. 2014. Genetic diversity of different indigenous chicken ecotypes using highly polymorphic MHC-linked and nonMHC microsatellite markers. Anim Genet Res 56:1-7. DOI: 10.1017/S2078633614000484

Putranto HD, Setianto J, Yumiati Y, Handika D. 2018. Analyses of body and chest morphometric comparison between two Indonesian local poultry species. Int J Agric Sci Technol 14(7): 1719-1730. www.ijataatsea.com.

Sitanggang EN, Hasnudin, Hamdan. 2016. Diversity of qualitative trait and morphometrics between Kampung, Bangkok, Katai, Birma, Bagon and Magon chicken in Medan. J Integr Anim Husb 2: $167-$ 189. [Indonesian]

Slice DE. 2007. Geometric morphometrics. Annu Rev Anthropol 36: 261281. DOI: 10.1146/annurev.anthro.34.081804.120613.

Tabassum F, Hoque MA, Islam F, Ritchil CH, Faruque MO, Bhuiyan AKFH. 2014. Phenotypic and morphometric characterization of indigenous chickens at Jhenaigati Upazila of Sherpur district in Bangladesh. SAARC J Agric 12 (2): 154-169. DOI: 10.3329/sja.v12i2.21927.

Wijayasena AMPSS, De Alwis DJ, Silva GLLP, Abeykoon MNDF. 2014. Cost benefit analysis of village chicken production in Puttalam district of Sri Lanka: A case study. Proc. Peradeniya University International Research Sessions, Peradeniya, Sri Lanka, 4-5 July 2014. www.dlib.pdn.ac.lk/archive/handle1/4768.

Wragg D, Mwacharo JM, Alcalde JA, Hocking PM, Hanotte O. 2012. Analysis of genome-wide structure, diversity and fine mapping of 
Mendelian traits in traditional and village chickens. Heredity 109:618. DOI: $10.1038 /$ hdy.2012.9.

Young NM, Linde-Medina M, Fondon JW, Hallgrímsson B, Marcucio RS. 2017 Craniofacial diversification in the domestic pigeon and the evolution of the avian skull. Nat Ecol Evol 1 (4): 95-111. DOI: 10.1038/s41559-017-0095. 